\title{
lodine supplementation during pregnancy of hypothyroid women treated with L-thyroxine neither influences neonatal TSH nor prevents decrease in maternal free thyroid hormone concentrations in second and third trimesters
}

Suplementacja jodowa u ciężarnych z niedoczynnością tarczycy leczonych L-tyroksyną nie wpływa na stężenia TSH noworodków ani nie zapobiega obniżeniu stężeń wolnych hormonów tarczycy u matek w drugim i trzecim trymestrze

\author{
Helena Jastrzębska ${ }^{1}$, Magdalena Kochman $^{1}, Z^{\prime b i g n i e w ~ B a r t o s z e w i c z}{ }^{2}$, \\ Mariusz Ottarzewski ${ }^{3}$, Romuald Dębski ${ }^{4}$, Wojciech Zgliczyński ${ }^{1}$ \\ ${ }^{1}$ Department of Endocrinology, Centre of Postgraduate Medical Education, Bielanski Hospital, Warsaw, Poland \\ ${ }^{2}$ Department of Internal Medicine and Endocrinology, Medical University of Warsaw, Poland \\ ${ }^{3}$ Institute of Mother's and Child's Health, Warsaw, Poland \\ ${ }^{4}$ Department of Obstetrics and Gynaecology, Centre of Postgraduate Medical Education, Bielanski Hospital, Warsaw, Poland
}

\begin{abstract}
Introduction: Pregnant women require about $250 \mu \mathrm{g}$ of iodine daily. Hypothyroid women treated with L-thyroxine do not utilise iodine, and metabolism of L-thyroxine tablets is an additional source of iodine for their foetuses.

The aim of the study was to evaluate the influence of iodine supplementation in hypothyroid pregnant women treated with L-thyroxine on neonate TSH concentration and maternal thyroid parameters.

Material and methods: Ninety-two pregnant women with primary hypothyroidism on adequate thyroid hormone replacement were voluntarily divided into two groups: "thyroxine" $(\mathrm{n}=38)$ treated with L-thyroxine only, and "thyroxine + iodine" $(\mathrm{n}=54)$ treated additionally with $150 \mu \mathrm{g} /$ day of iodine since $10^{\text {th }}$ gestational week.

Primary outcomes were the maternal thyroid function tests (TSH, fT4, fT3) and neonatal TSH concentrations at the $3-4^{\text {th }}$ day of life. Urinary iodine concentration was measured at first and third trimester to compare iodine status in both groups.

Results: Iodine supplementation significantly increased median urinary ioduria in the third trimester (from $95.15 \mu \mathrm{g} / \mathrm{L}$ to $151.50 \mu \mathrm{g} / \mathrm{L}$ ), but did not prevent the decrease of maternal fT 4 and fT 3 concentrations in the second and third trimester. Median neonate TSH concentration in both groups was within normal range, but was 33\% higher in the "thyroxine + iodine" than in the "thyroxine" group (1.91 mU/L vs. $1.34 \mathrm{mU} / \mathrm{L}$ ). Moreover, $8.77 \%$ of newborns in the "thyroxine + iodine" group had TSH > $5 \mathrm{mIU} / \mathrm{L}$.

Conclusions: We did not find evidence for a positive influence of iodine supplementation on thyroid function of either hypothyroid pregnant women sufficiently treated with L-thyroxine or their neonates. (Endokrynol Pol 2016; 67 (4): 367-374)

Key words: pregnancy; hypothyroidism; iodine supplementation; neonatal TSH; ioduria
\end{abstract}

\section{Streszczenie}

Wstęp: U ciężarnych rekomendowana jest zwiększona podaż jodu pokrywająca zapotrzebowanie kobiety i dziecka. Tarczyca ciężarnej z niedoczynnością nie zużywa jodu. Jod dostarczony w diecie, suplementach oraz pochodzący z metabolizmu tyroksyny stanowi źródło wyłącznie dla płodu.

Celem pracy była ocena wpływu suplementacji jodowej u ciężarnych z niedoczynnością tarczycy na stężenia TSH noworodków i parametry tarczycowe matek.

Materiał i metody: Badanie przeprowadzono w grupie 92 ciężarnych z pierwotną niedoczynnością tarczycy wyrównaną w trakcie leczenia L-tyroksyną podzielono na dwie grupy: „tyroksyna” $(n=38)$ leczone jedynie tyroksyną i “tyroksyna + jod” $(n=54)$ otrzymujące tyroksynę i od 10. tygodnia ciąży jod $150 \mu \mathrm{g} /$ dobę.

U matek oznaczano TSH, fT4, fT3 w każdym trymestrze a u noworodków TSH w 3-4 dobie życia. Zaopatrzenie w jod oceniano na podstawie jodurii badanej w 1 . i 3. trymestrze.

Wyniki: Suplementacja jodowa spowodowała istotne zwiększenie mediany jodurii z 95,15 $\mu \mathrm{g} / 1$ do 151,50 $\mu \mathrm{g} / \mathrm{l}$, jednak nie zapobiegła obniżeniu stężeń fT4 i fT3 w 2. i 3. trymestrze. W obu grupach mediana stężeń TSH noworodków utrzymywała się w granicach normy, ale była o $33 \%$ wyższa w grupie "tyroksyna + jod" niż w grupie "tyroksyna” $(1,91 \mathrm{mU} / 1$ vs. 1,34 mU/l). Tylko w grupie "tyroksyna + jod” stwierdzono u noworodków stężenie TSH $>5 \mathrm{mIU} / \mathrm{l}$ co dotyczyło $8,77 \%$ badanych.

Wnioski: Nie uzyskano dowodów na pozytywny wpływ suplementacji jodowej u ciężarnych z niedoczynnością tarczycy właściwie wyrównanych L-tyroksyną na TSH noworodków. Nie zaznaczył się także wpływ na parametry tarczycowe u kobiety ciężarnej. (Endokrynol Pol 2016; 67 (4): 367-374)

Słowa kluczowe: ciąża; niedoczynność tarczycy; suplementacja jodowa; TSH noworodków; joduria 


\section{Introduction}

Iodine deficiency during pregnancy may result in insufficient maternal and foetal thyroid hormone synthesis and may lead to impaired brain development of the child [1]. On the other hand, iodine excess may inhibit foetal thyroid, which begins to synthesise thyroid hormones at about the 10th week of pregnancy [2], causing hypothyroidism and goitre [3].

The assessment of iodine intake in the population can be made using urinary iodine concentration and indirectly by measurement of TSH concentration in neonates [4]. According to WHO experts, the median urinary iodine concentration in pregnant women is between 150 and $249 \mu \mathrm{g} / \mathrm{L}$, and a percentage of neonates in their $3^{\text {rd }}-4^{\text {th }}$ day of life with TSH level higher than $5 \mathrm{mU} / \mathrm{L}$ below $3 \%$ indicates adequate iodine intake [5].

With reference to increased dietary iodine requirements during pregnancy, WHO/UNICEF/ICCIDD recommend a daily iodine intake during pregnancy of 200 to $300 \mu \mathrm{g}$, mean $250 \mu \mathrm{g}$, maximally $500 \mu \mathrm{g}$ [4]. Therefore, to ensure an adequate iodine supply for the mother and her child in many European countries pregnant and breastfeeding women are advised to receive an additional daily oral dose of $100-200 \mu \mathrm{g}$ of potassium iodide. There is no separate recommendation for hypothyroid women in whom the thyroid gland is not able to synthesise hormones and who are treated with L-thyroxine. In these cases, not only iodine provided with food and released during metabolism of maternal hormones, but also iodine derived from L-thyroxine tablets remains at the disposal of the child's thyroid [6]. Following the metabolism of $100 \mu \mathrm{g}$ of L-thyroxine, about $60 \mu \mathrm{g}$ of iodine is released, which, together with the dietary iodine intake pool, remains at the disposal of the thyroid of the child [6]. The neonate thyroid hormone synthesis begins at about the $10^{\text {th }}$ week of pregnancy. To the best of our knowledge, there are no data available regarding iodine supplementation in pregnant hypothyroid women treated with substitutive doses of L-thyroxine. Thus, we aimed to estimate the influence of iodine supplementation in hypothyroid pregnant women receiving L-thyroxine on their thyroid status evaluated by measurement of TSH, fT3, and fT4 concentrations, as well as on the thyroid function of their newborns assessed by neonate TSH concentration.

\section{Material and methods}

\section{Subjects}

The study population included 96 pregnant Caucasian women with a history of primary hypothyroidism. All participants were consecutively recruited from a single endocrinology outpatient clinic. The study lasted from 2008 until 2013.

Ninety-two patients completed the study because there were two miscarriages at the $12^{\text {th }}$ week of gestation, one missed abortion at the $26^{\text {th }}$ weeks of gestation, and one missed data collection due to refusal to continue the study.

Seventeen of the patients were treated because of subclinical hypothyroidism, in all cases caused by Hashimoto disease. All patients were physically examined and had TSH, fT3, and fT4 concentrations measured every 4-6 weeks. They were on a standard diet and were treated with L-thyroxine only before pregnancy and until the end of the $10^{\text {th }}$ week of gestation. Thereafter, the studied group was divided into two subgroups: the "thyroxine" group, consisting of 38 subjects who continued with appropriate dose of L-thyroxine only; and the "thyroxine + iodine" group -54 subjects who additionally to L-thyroxine received a standard dose of $150 \mu$ g iodine daily as potassium iodide in a separate pill. Commercially available multivitamin and mineral supplements were not used. The enrolment to subgroups was made on a voluntary basis. The basic characteristics of the subgroups are presented in Table I.

During pregnancy and perinatal period the women were not exposed to the iodinated contrast media, thyroid affecting medications, iodinated antiseptics, or cigarette smoking.

The study protocol was reviewed and approved by the Ethics Committee of the Centre of Postgraduate Medical Education in Warsaw, Poland. Signed informed consent form was obtained from all patients.

\section{Analytical methods}

Mothers' blood TSH, free T3 (fT3), and free T4 (fT4) concentrations in samples collected at 8-10, 22-24, and 34-36 weeks of pregnancy were used for statistical analysis, the first and third of them corresponding to the urinary iodine excretion measurements. To avoid confounding factors, the samples were taken in the morning before L-thyroxine as well as iodine ingestion. Serum was separated by centrifugation and the hormone concentration was assayed immediately.

Quantitative analyses of TSH, fT3, and fT4 were performed by a chemiluminescent immunoassay (EURO/ DPC, UK) using an Immulite 2000 automatic analyser. The manufacturer's reference ranges for non-pregnant adult in these kits were as follows: TSH 0.4-4.0 mIU/L (sensitivity $0.004 \mathrm{mIU} / \mathrm{L}$, intra-assay coefficient of variance - CV 3.8-12.5\%), fT4 11.5-22.7 pmol/L (sensitivity $3.2 \mathrm{pmol} / \mathrm{L}$, intra-assay CV $3.0-7.8 \%$ ), and fT3 1.8 $-4.2 \mathrm{pg} / \mathrm{mL}$ (sensitivity $1.0 \mathrm{pg} / \mathrm{mL}$, intra-assay $\mathrm{CV}$ $4.3-9.1 \%)$, respectively. 
Table I. Basic characteristics of the studied groups

Tabela I. Podstawowa charakterystyka badanych grup

\begin{tabular}{|c|c|c|}
\hline Parameters & "Thyroxine" group & "Thyroxine + iodine" group \\
\hline Number of patients & 38 & 54 \\
\hline \multicolumn{3}{|l|}{ Aetiology of hypothyroidism: } \\
\hline Hashimoto's thyroiditis & 31 & 46 \\
\hline Thyroidectomy propter nodular thyroid disease & 2 & 2 \\
\hline Thyroidectomy propter Graves' disease & 1 & 1 \\
\hline Thyroidectomy and radioiodine therapy propter thyroid cancer & 0 & 1 \\
\hline Thyroidectomy, radioiodine and external radiotherapy propter thyroid cancer & 1 & 0 \\
\hline Radioiodine therapy propter Graves' disease & 2 & 4 \\
\hline Thyroidectomy and radioiodine therapy propter Graves' disease and thyroid cancer & 1 & 0 \\
\hline \multicolumn{3}{|l|}{ Severity of hypothyroidism } \\
\hline overt & 27 & 46 \\
\hline subclinical & 9 & 8 \\
\hline \multicolumn{3}{|l|}{ Coexisting disorders: } \\
\hline Celiac disease & 1 & 0 \\
\hline Pernicious anaemia & 1 & 0 \\
\hline Hypoparathyroidism & 1 & 0 \\
\hline Diabetes type 1 & 0 & 1 \\
\hline \multicolumn{3}{|l|}{ Conception: } \\
\hline Natural & 38 & 47 \\
\hline In vitro fertilisation & 0 & 6 \\
\hline Insemination & 0 & 1 \\
\hline Age (years) mean $\pm S D$ & $30.16 \pm 3.5$ & $30.10 \pm 3.53$ \\
\hline
\end{tabular}

Urinary iodine excretion was evaluated in every subject in the 1st and 3rd trimester of pregnancy. Taking into account the high diurnal and day-to-day variability of urinary iodine excretion, we assessed urinary iodine concentration for every pregnant subject four times: twice at the $10^{\text {th }}$ week of gestation and twice at the $34^{\text {th }}-36^{\text {th }}$ week of gestation. It was measured in a spot of morning urine sample by the catalytic cerium/ /arsenic method based on the Sandell-Kolthoff reaction, which was preceded by alkaline ashing [7]. TSH concentration in neonates was evaluated as a part of the neonatal screening protocol. The procedure is based on determination of TSH by a two-site IRMA method in dried blood spots obtained by the heel puncture at the $3^{\text {rd }} 4^{\text {th }}$ day of life. In Poland, values $\geq 15 \mathrm{mIU} / \mathrm{L}$ in whole blood are considered abnormal and require further assessment for congenital hypothyroidism.

\section{Statistical analyses}

Statistical analyses were performed using STATISTICA 9.0 PL.

The Kolmogorov-Smirnov test was used to estimate the normal distribution of evaluated parameters. The
Student $\mathrm{t}$ test was used for normally distributed data, while Wilcoxon-matched-paired test and the BonferoniHolm adjustment were used for data not normally distributed. The Spearman test was performed to calculate the correlations between groups. The values were reported as median, minimum, and maximum. Statistical significance was accepted at $\mathrm{P}<0.05$.

\section{Results}

All women remained euthyroid throughout pregnancy, and that fact was confirmed by serum TSH level, adopted as a concentration above $0.4 \mathrm{mIU} / \mathrm{L}$ and below $2.5 \mathrm{mIU} / \mathrm{L}$. Their serum fT4 and fT3 concentrations remained within normal range for the general population.

Median urinary iodine concentration at the $10^{\text {th }}$ week of pregnancy was below the optimal range for pregnant women both in the "thyroxine" and "thyroxine + iodine" groups (median \pm IQR: $83.15 \pm 41.03 \mu \mathrm{g} / \mathrm{L}$ and $95.15 \pm 69.45 \mu \mathrm{g} / \mathrm{L}$, respectively), which indicated mild iodine deficiency according to the WHO criteria (Fig. 1). In the first trimester, only 5 of 38 women of the "thyroxine" group and 11 of 54 patients of the 
Table II. Selected parameters in pregnant hypothyroid women and their offspring

Tabela II. Wybrane parametry u kobiet ciężarnych $z$ niedoczynnościq tarczycy $i$ ich dzieci

\begin{tabular}{|c|c|c|c|c|}
\hline \multicolumn{4}{|l|}{ Time of examination } & p \\
\hline Mother & Thyroxine dose $[\mu \mathrm{g} / \mathrm{d}]$ & & & \\
\hline \multirow[t]{7}{*}{ First trimester } & mean $\pm S D$ & $86.40 \pm 44.60$ & $83.142 \pm 38.32$ & ns \\
\hline & range & $50-200$ & $50-175$ & \\
\hline & Thyroxine dose $[\mu \mathrm{g} / \mathrm{kg} / \mathrm{d}]$ & & & \\
\hline & mean $\pm S D$ & $1.38 \pm 0.46$ & $1.40 \pm 0.69$ & ns \\
\hline & range & $0.51-2.21$ & $0.62-3.12$ & \\
\hline & Urinary iodine excretion $[\mu \mathrm{g} / \mathrm{L}]$ & & & \\
\hline & Median $\pm \mathrm{IQR}$ & $83.15 \pm 41.03$ & $95.15 \pm 69.45$ & ns \\
\hline Mother & Thyroxine dose $[\mu \mathrm{g} / \mathrm{d}]$ & & & \\
\hline \multirow[t]{7}{*}{ Third trimester } & mean \pm SD & $119.0 \pm 51.59$ & $100.0 \pm 41.62$ & ns \\
\hline & range & $75-200$ & $100-200$ & \\
\hline & Thyroxine dose $[\mu \mathrm{g} / \mathrm{kg} / \mathrm{d}]$ & & & \\
\hline & mean $\pm S D$ & $1.57 \pm 0.48$ & $1.50 \pm 0.58$ & ns \\
\hline & range & $0.89-2.564$ & $0.89-2.86$ & \\
\hline & Urinary iodine excretion $[\mu \mathrm{g} / \mathrm{L}]$ & & & \\
\hline & Median \pm IOR & $101.09 \pm 81.66$ & $151.50 \pm 80.77$ & $<0.01$ \\
\hline Neonate & $\mathrm{TSH}[\mathrm{mU} / \mathrm{L}]$ & & & \\
\hline \multirow[t]{3}{*}{$3-4$ days after birth } & Median $\pm \mathrm{IQR}$ & $1,34 \pm 2.21$ & $1.91 \pm 2.41$ & ns \\
\hline & range & $0.01-3.86$ & $0.01-9.48$ & \\
\hline & $\begin{array}{l}\text { Number (percentage) of newborns } \\
\text { with TSH }>5 \mathrm{mU} / \mathrm{L}\end{array}$ & 0 & $5 / 57(8.77 \%)$ & \\
\hline
\end{tabular}

ns - non-significant

"thyroxine and iodine" group had adequate urinary iodine excretion (Fig. 2). Introduction of iodine supplementation in the "thyroxine + iodine" group resulted in a significant increase of median urinary iodine concentration at the $3^{\text {rd }}$ trimester up to $151.50 \pm 80.77 \mu \mathrm{g} / \mathrm{L}$ $(\mathrm{p}<0.001)$, while in the "thyroxine" group the median urinary iodine excretion did not change and remained low $(101.09 \pm 81.66 \mu \mathrm{g} / \mathrm{L})$. The percentage of individuals with urinary iodine concentration over $150 \mu \mathrm{g} / \mathrm{L}$ in the "thyroxine + iodine" group increased significantly but remained steady in the group treated with thyroxine alone (Fig. 2).

In both groups, serum fT4 concentrations significantly decreased in the second and third trimester when compared with the first. In the "thyroxine + iodine" group, TSH and fT3 levels were also significantly lower in the third trimester when compared with the first (Fig. 1). TSH and fT3 concentrations did not differ between the "thyroxine" and "thyroxine + iodine" groups in any trimester, while fT4 level was lower in the third trimester in the "thyroxine + iodine" group.
TSH concentrations were analysed in 39 neonates in the "thyroxine" group and 57 in the "thyroxine + iodine" group (as one of the triplets died in the first day of life) (Table III). The neonate TSH concentrations both in the "thyroxine" and the "thyroxine + iodine" groups were within the normal range with median TSH level of $1.34 \mathrm{mIU} / \mathrm{L}$ and $1.91 \mathrm{mIU} / \mathrm{L}$, respectively, and did not differ between the groups. The newborn TSH concentration above $5 \mathrm{mIU} / \mathrm{L}$ was found in five neonates $(5.11,5.33,5.66,7.38$, and $9.26 \mathrm{mU} / \mathrm{L}$, respectively). Interestingly, all of those children were from mothers of the "thyroxine + iodine" group $(5 / 57=8.77 \%)$, who were treated because of overt hypothyroidism (four of them due to Hashimoto's thyroiditis and one - after strumectomy propter nodular goitre) (Table II). One child with TSH concentration of $5.66 \mathrm{mIU} / \mathrm{L}$ had a twin brother in whom the TSH level was found to be $0.5 \mathrm{mIU} / \mathrm{L}$. Duration of pregnancy did not differ in both groups and was 37.68 weeks and 39.0 weeks, respectively. The prevalence of gestational diabetes was similar in both groups and remained within the aver- 

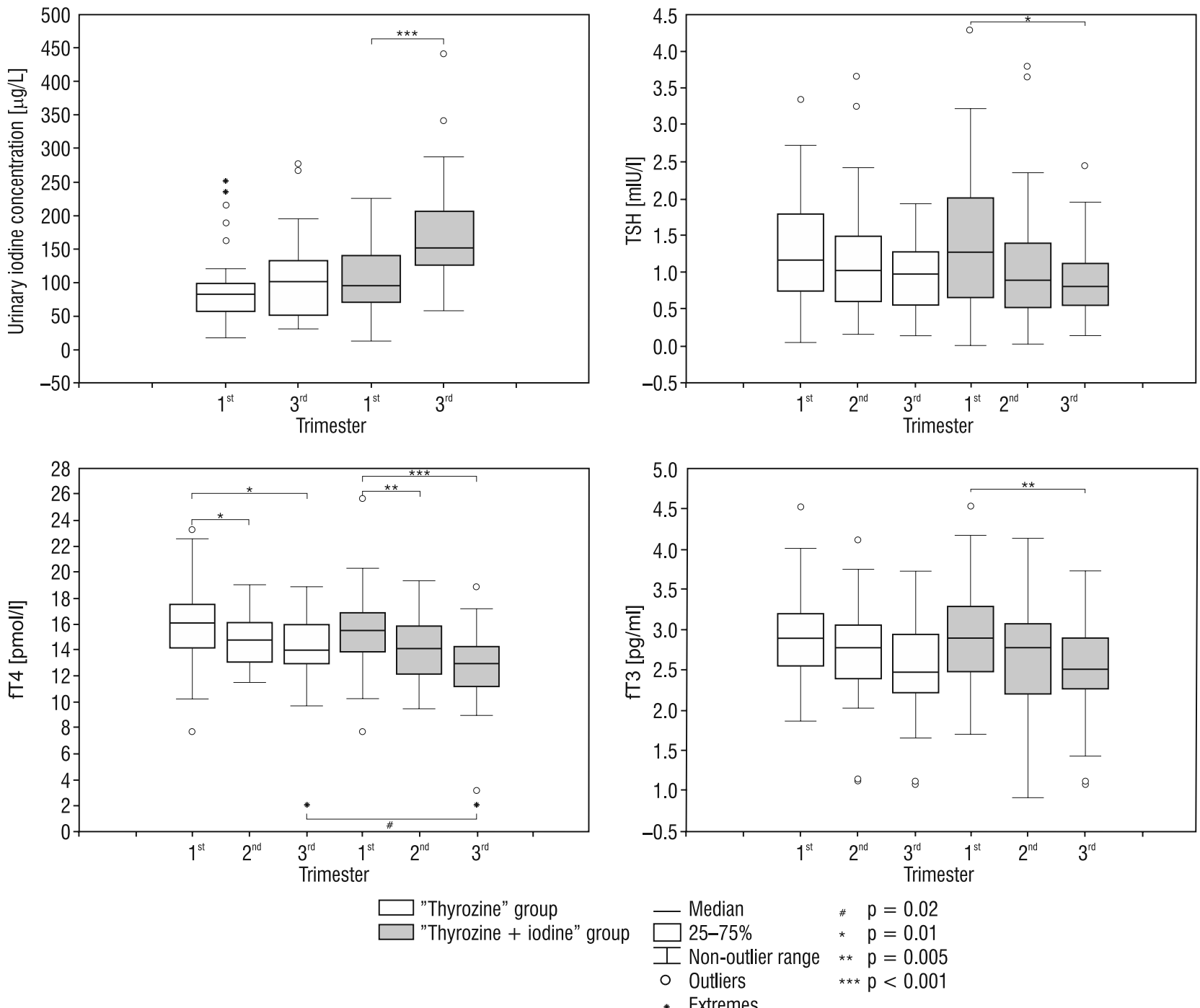

Figure 1. Evolution of urinary iodine, TSH, fT4, and fT3 concentrations in hypothyroid women treated with thyroxine alone or with thyroxine and iodine at each trimester of pregnancy. Data are presented as median $\pm I Q R$. Significant differences in urinary iodine excretion as well as TSH, fT4, and fT3 concentrations between the trimesters in each of the two groups are shown in the diagrams

Rycina 1. Zmiany stężeń jodu w moczu porannym oraz TSH, fT4 ifT3 w poszczególnych trymestrach ciąży u ciężarnych z niedoczynnościa tarczycy leczonych sama L-tyroksyna lub L-tyroksyna i preparatem jodu. Dane przedstawione jako mediana $\pm I Q R$. Na wykresach zaznaczono istotne różnice w jodurii oraz stężeniach TSH, fT4 ifT3 pomiędzy poszczególnymi trymestrami w obu badanych grupach

age range (below 10\%) for pregnant women (Table III). Perinatal complications occurred in two cases from the "thyroxine" group. One patient developed sclerosis multiplex and another one suffered an ischaemic stroke with left-sided hemiplegia. In this particular case previously undiagnosed foramen in atrial septum was found thereafter.

\section{Discussion}

There are four parameters recommended for the assessment of iodine status in human populations: urinary iodine concentration, goitre rate in school-age children, thyroglobulin concentration, and neonatal
TSH concentration [2]. Urinary iodine concentration is a sensitive indicator of a recent, daily iodine intake. Thyroglobulin concentration indicates iodine supply during the preceding weeks to months, whereas thyroid volume corresponds to long-term iodine nutrition lasting months to years [2]. Neonatal TSH is a marker of iodine supply during late foetal life.

We found it reasonable to question whether standard iodine supplementation in hypothyroid pregnant women on adequate thyroid hormone replacement influence thyroid function of their neonates. In Poland an iodine prophylaxis program has been implemented since 1997, with modification in 2010, which includes mandatory iodisation of household salt with 


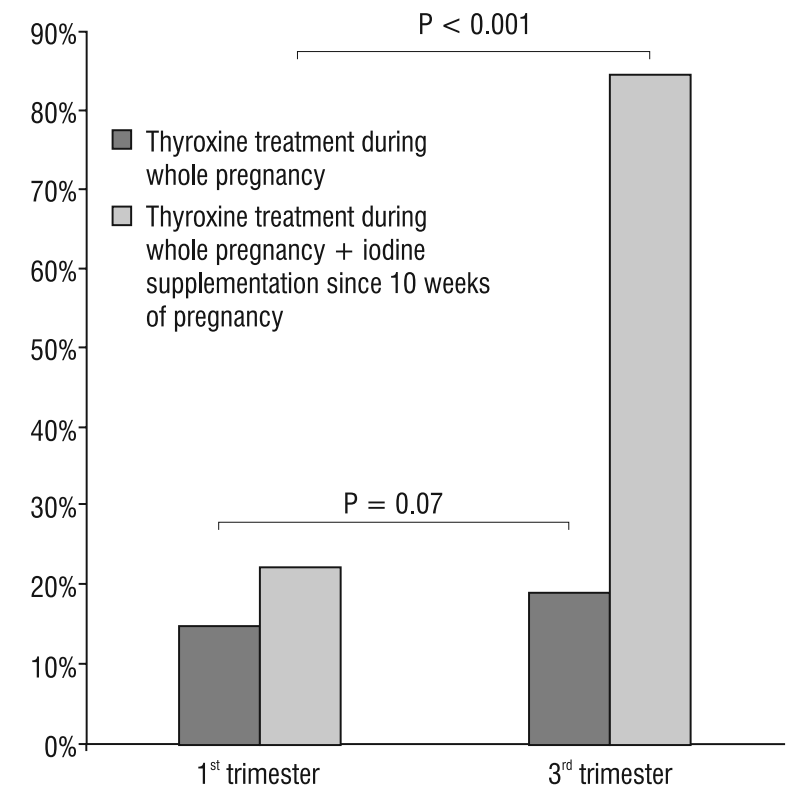

Figure 2. Percentage of hypothyroid pregnant women treated with thyroxine or thyroxine + iodine with urinary iodine excretion over $150 \mu \mathrm{g} / \mathrm{L}$

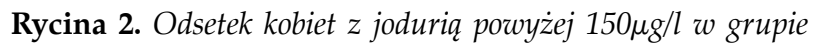
ciężarnych z niedoczynnością tarczycy leczonych sama L-tyroksyna oraz w grupie leczonych L-tyroksyna i preparatem jodu

Table III. The course and outcome of pregnancy Tabela III. Przebieg ciąży i porodu

\begin{tabular}{|c|c|c|}
\hline & $\begin{array}{l}\text { "Thyroxine" } \\
\text { group }\end{array}$ & $\begin{array}{c}\text { "Thyroxine + } \\
+ \text { iodine" } \\
\text { group }\end{array}$ \\
\hline Number of women & 38 & 54 \\
\hline Gestational diabetes & $2(5.26 \%)$ & $3(5.56 \%)$ \\
\hline therapy & $2-$ diet & $\begin{array}{l}2 \text { - diet, } \\
1 \text { - diet } \\
+ \text { insulin }\end{array}$ \\
\hline Multiple pregnancies & $1(2.63 \%)$ & $3(5.56 \%)$ \\
\hline number of infants & 2 (twins) & $\begin{array}{c}7 \text { (2 twins, } \\
1 \text { triplets) }\end{array}$ \\
\hline \multicolumn{3}{|l|}{ Mode of delivery } \\
\hline vaginal & $36(94.73 \%)$ & $49(90.74 \%)$ \\
\hline caesarean & $2(5.26 \%)$ & $5(9.25 \%)$ \\
\hline Pre-term delivery & $1(2.6 \%)$ & $4(7.4 \%)$ \\
\hline Week of pregnancy at childbirtha & $\begin{array}{c}37.68 \pm 6.07 \\
(36-41)\end{array}$ & $\begin{array}{c}39.0 \pm 1.48 \\
(27-41)\end{array}$ \\
\hline Number of neonates & 39 & 58 \\
\hline
\end{tabular}

a - mean $\pm S D$ (range)

$30 \pm 10 \mathrm{mg} \mathrm{KI} / \mathrm{kg}$ salt or $39 \pm 13 \mathrm{mg} \mathrm{KIO} / \mathrm{kg}$ salt and supplementation of pregnant and breastfeeding women with an additional $150 \mu \mathrm{g}$ of iodine daily [8]. Despite the fact that Poland in 2003 was considered by the WHO, UNICEF, and ICCIDD to be a country with sufficient iodine supply [9], we did not find satisfactory urinary iodine concentrations in the group under study. Median ioduria at the first trimester of gestation in hypothyroid women being efficiently treated with L-thyroxine was $85.28 \mu \mathrm{g} / \mathrm{L}$, which corresponds to the epidemiological criteria of insufficient iodine supply [10]. Before introducing iodine supplementation only $17.4 \%$ of our population of 94 subjects had urinary iodine concentration above $150 \mu \mathrm{g} / \mathrm{L}$. Iodine supplementation resulted in an expected increase in median morning ioduria-as well as an increase in the percentage of patients with desirable urinary iodine concentration above $150 \mu \mathrm{g} / \mathrm{L}$ to $61.1 \%$. We realise that the number of participants in our study is not adequate to assess iodine sufficiency in the population [11]; however, the increase in iodine urinary excretion confirms additional iodine intake in the "thyroxine + iodine" group.

In healthy pregnant women fT4 concentrations decrease at the second and third trimester [12]. This phenomenon was considered to be a result of changes in thyroxine-binding globulin and albumin concentrations $[13,14]$ or of a true hypothyroxinaemia, possibly reflecting iodine deficiency [15]. Brucker et al. reported in women with normal thyroid function a drop of both fT4 and fT3 levels after the first trimester of pregnancy, with no influence of iodine supplementation [16]. Similarly, in our material of hypothyroid women treated with L-thyroxine, we observed a significant decrease of fT4 levels during pregnancy irrespectively of iodine supplementation, which was not accompanied by an increase in TSH concentration. Moreover, fT4 was significantly lower in the "thyroxine + iodine" than in the "thyroxine" group. The concentration of fT3 decreased significantly in the "thyroxine + iodine" group only; however, a similar tendency was seen in the "thyroxine" group (Fig. 1). Our results seem to confirm that a drop in fT4 and fT3 levels at second and third trimester is a physiological phenomenon in pregnancy and not a consequence of iodine deficiency.

Proper iodine supply ensures normal thyroid function of the child, which is essential for its somatic and neurological development $[1,17]$. Neonatal TSH is an important marker of iodine supply during later gestation, as its concentration correlates with the thyroid hormone level of the foetus [1]. Insufficient supply of iodine leads to depletion of thyroid hormone production and consequently to overstimulation of the thyroid gland by TSH [18]. However, whether newborn TSH measured in 3-4 days after birth is a sensitive indicator of mild iodine deficiency during pregnancy is currently being discussed $[19,20]$. According to the WHO criteria, in 
a population with optimal iodine supply the percentage of neonates with TSH values above $5 \mathrm{mIU} / \mathrm{L}$ is under $3 \%$ and increases to $3-19.9 \%$ in mild iodine deficiency, to $20-39.9 \%$ in moderate deficiency, and above $40 \%$ in severe iodine deficiency [5]. TSH values above $20 \mathrm{mIU} / \mathrm{L}$ (in Poland $>15 \mathrm{mIU} / \mathrm{L}$ ) require recall of the infant for further examination to exclude congenital hypothyroidism [21-23]. In our group newborn TSH values (0.01-9.48 mIU/L) were within the normal range, and none of the children required re-examination. Surprisingly, hypothyroid women treated with L-thyroxine and iodine supplementation had children with $33 \%$ higher TSH values than those who did not receive iodine supplements, although the difference was not significant. Moreover, all of the neonates with TSH levels $>5 \mathrm{mIU} / \mathrm{L}$ were from mothers of the "thyroxine + iodine" group treated for overt hypothyroidism, without the residual functional thyroid tissue. It should be noted that none of the subjects took additional supplements containing iodine, and deliveries were conducted in departments that did not use iodine-containing disinfectants. Although, according to data from literature, the use of these substances results in an increase of TSH values above $5 \mathrm{mIU} / \mathrm{L}$ in $17.6 \%$ of neonates [24, 25], in our study their influence cannot be taken into account. Our findings could be explained by the inhibitory effect of iodine on foetal thyroid [26]. This kind of influence is especially marked in the iodine-deficient population, and is less pronounced when iodine supply is optimal [27]. Our data are inconsistent with some other studies indicating that increased frequency of elevated TSH values can serve as a marker of iodine deficiency [28]. We took into consideration the need to ensure the optimal iodine supply for pregnant women, as well as the consequences of iodine deficiency, especially for brain development of the foetus. However, in the group of hypothyroid women treated with L-thyroxine we did not show a positive influence of iodine supplementation on the foetal thyroid function parameter, which is the neonate TSH concentration. Similar results were obtained by other authors, who measured TSH concentrations in umbilical cord blood samples of children of healthy women receiving iodine supplementation in a dose of $150 \mu \mathrm{g}$ daily [29]. Velasco et al. also found an increase of neonatal TSH in a group of pregnant women receiving 50-200 $\mu \mathrm{g}$ of iodine daily, but based on psychomotor tests performed at 3-18 months of age he also showed that iodine supplementation positively influenced on the neurological development of children [30]. However, recently these authors did not observe the positive impact of iodine supplementation during pregnancy on infant neurocognitive development [31], whereas Rebagliato et al. showed decreased psychomotor and mental index scores of infants in the first year of life, whose mothers consumed $\geq 150 \mu \mathrm{g}$ /day of iodine from supplements [32].

The vast majority of our subjects were women with autoimmune thyroid diseases. A limitation of our study was that we did not assess anti-TSH receptor binding antibodies, which could potentially cross the placenta and influence the foetal thyroids. Four of five children with $\mathrm{TSH}>5 \mathrm{mIU} / \mathrm{L}$ were from women with Hashimoto's disease, and we cannot exclude a potential effect of anti-TSH blocking antibodies on the foetal thyroids. We also took into account the possible inhibitory effect of iodine on the foetal thyroid, however, there was no correlation between neonatal TSH concentrations and maternal median urinary iodine excretion. Moreover, the median ioduria in mothers of children with elevated TSH concentrations did not differ from the rest of the "thyroxine + iodine" group.

One of the most common causes of elevated neonatal TSH concentration is prematurity. In our group, 5 of 96 babies were premature (one from the 'thyroxine" and four from the "thyroxine + iodine" group). Only one of them had TSH concentration $>5 \mathrm{mIU} / \mathrm{L}$ (5.66 mIU/L), while the TSH concentrations of the rest were within the range $0.51-3.86 \mathrm{mIU} / \mathrm{L}$.

It should be expected that an extremely high dose of iodine may cause foetal hypothyroidism. The ability of foetal thyroid to escape the Wolff-Chaikoff mechanism as well as to avoid hypothyreosis is not entirely possible before 36 weeks of gestation [33]. The WHO recommendations estimate a daily dose of iodine above $500 \mu \mathrm{g}$ to be excessive for pregnant women [4], while the US Institute of Medicine defines an upper limit in pregnancy on the level of $1100 \mu \mathrm{g}$ per day [34]. Inclusion time of iodine supplementation as well as its beneficial effect on neurodevelopment of children is currently being discussed. Velasco et al. showed a positive effect of iodine supplementation starting at the $10^{\text {th }}$ weeks of gestation [30], whereas Berbel et al. observed that iodine lost its favourable influence when implemented after the $10^{\text {th }}$ week of pregnancy [35]. The group of Berbel treated with $200 \mu \mathrm{g}$ iodine daily 92 women since 4-6 weeks of gestation, 102 women since 10-12 weeks of gestation, and 151 women after delivery. Based on the neurocognitive tests carried out at 18 months of age, those authors revealed a positive influence of this treatment on children's development only in a group supplemented since 4-6 weeks of gestation, and they did not find differences between the group supplemented since the $10^{\text {th }}$ week of gestation and those not receiving supplementation during foetal life [35]. Liesenkortter et al. implemented $300 \mu \mathrm{g}$ of iodine in 38 women since 10-12 weeks of pregnancy. Those authors compared the results with those of 70 non-treated women, and they did not show any difference in the neonatal TSH 
concentrations [36]. It seems that the optimal dose of iodine, the strategy of its implementation in pregnant women at moderate iodine deficient areas, as well as the determination of the highest safe dose are still open questions. We realise that a limitation of our work is the small number of patients and the participation in the study of women both with overt and subclinical hypothyroidism. Women with partially preserved functional thyroid tissue frequently need lower increment of L-thyroxine dose during pregnancy than patients without functioning gland, which suggests that their residual thyroid cells may to a certain extent utilise iodine for thyroid hormone synthesis. However, the preliminary results encourage us to continue research work. It seems reasonable to extend the study and to separate the groups with overt and subclinical hypothyroidism, as well as to assess foetal/neonatal thyroid by ultrasound. We conclude that our results do not provide evidence of a positive influence of iodine supplementation on thyroid function of hypothyroid pregnant women sufficiently treated with L-thyroxine or their neonates. The results indicate the existence of iodine insufficiency in the population of Polish pregnant women, which might explain the particular sensitivity of foetal thyroid to the inhibitory effect of iodine.

\section{References}

1. de Escobar GM, Obregón MJ, del Rey FE. Maternal thyroid hormones early in pregnancy and fetal brain development. Best Pract Res Clin Endocrinol Metab 2004; 18: 225-248.

2. Zimmermann MB. Iodine Deficiency. Endoc Rev 2009; 30: 376-408.

3. Theodoropoulos T, Braverman LE, Vagenakis AG Iodide induced hypothyroidism: a potential hazard during perinatal life. Science 1979; 205: 502-503.

4. WHO/UNICEF/ICCIDD Assessment of Iodine Deficiency Disorders and Monitoring Their Elimination: A Guide for Programme Managers, 2007; 3rd ed. WHO Press, Geneva, Switzerland.

5. WHO Urinary iodine concentration for determining iodine status in populations. 2013; Vitamin and Mineral Nutrition Information System.

6. Delange F. Metabolism of thyroid hormones. In: Braverman LE, Utiger RD (eds.) The Thyroid. A Fundamental and Clinical Text. Lippincott, Philadelphia, 2000.

7. Drożdż R. Catalytic method of iodide ion determination in urine. Endokrynol Pol 1992; 43 Suppl. 1:83-89.

8. Szybiński Z. Iodine deficiency in pregnancy - a continuing public health problem. Endokrynol Pol 2005; 56: 65-71.

9. Szybiński Z, Delange F, Lewiński A et al. A programme of iodine supplementation using only iodised household salt is efficient - the case of Poland. Eur J Endocrinol 2001; 144: 331-337.

10. Zimmermann MB, Jooste PL, Pandav CS. The iodine deficiency disorders. Lancet 2008; 372:1251-1262

11. Andersen S, Karmisholt J, Pedersen KM et al. Reliability of studies of iodine intake and recommendations for number of samples in groups and in individuals. Br J Nutr 2008; 99: 813-818.

12. Glinoer $D$ The regulation of thyroid function in pregnancy: pathways of endocrine adaptation from physiology to pathology. Endocr Rev 1997; 18: 404-433.

13. Roti E, Gardini E, Minelli R et al. Thyroid function evaluation by different commercially available free thyroid hormone measurement kits in term pregnant women and their newborns. J Endocrinol Invest 1991; 14: 1-9.
14. Lee RH, Spencer CA, Mestman JH et al. Free T4 immunoassays are flawed during pregnancy. Am J Obstet Gynecol 2009; 200: 260 e1-260.e6.

15. de Escobar GM, Obregon MJ, del Rey FM. Is neuropsychological development related to maternal hypothyroidism or to maternal hypothyroxinemia? J Clin Endocrinol Metab 2000; 85: 3975-3987.

16. Brucker-Davis F, Panaïa-Ferrari P, Gal J et al. Iodine Supplementation throughout Pregnancy Does Not Prevent the Drop in FT4 in the Second and Third Trimesters in Women with Normal Initial Thyroid Function. Eur Thyroid J 2013; 2: 187-194.

17. Zoeller RT, Rovet J. Timing of thyroid hormone action in the developing brain: clinical observations and experimental findings. J Neuroendocrinol 2004; 16: 809-818.

18. Zimmermann MB, Aeberli I, Torresani T et al. Increasing the iodine concentration in the Swiss iodized salt program markedly improved iodine status in pregnant women and children: a 5-y prospective national study. Am J Clin Nutr 2005; 82: 388-392.

19. 1llig $\mathrm{R}$, Torresani T. TSH determination in dried blood: a reliable, efficient, and inexpensive method for neonatal screening. In: Burrow GN, Dussault JH (eds) Neonatal Thyroid Screening. Raven Press, New York, 1980; 87-94.

20. Vandevijvere S, Coucke W, Vanderpas J et al. Neonatal thyroid-stimulating hormone concentrations in Belgium: a useful indicator for detecting mild iodine deficiency? PLoS One 2012; 7: e47770. doi: 10.1371/journal. pone.0047770. Epub 2012 Oct 24.

21. Ołtarzewski M, Tylek-Lemańska D, Szymborski J. Preliminary evaluation of changes in blood spot TSH levels based on the neonatal screening programme in Poland. Endokrynol Pol 1998; 49 (Suppl. 1): 63-71.

22. Ołtarzewski M, Szymborski J. Neonatal hypothyroid screening in monitoring of iodine deficiency and iodine supplementation in Poland. J Endocrinol Invest 2003; 26 (Suppl. 2): 27-31.

23. Hubalewska-Dydejczyk A, Lewiński A, Milewicz A et al. Managemen of thyroid diseases during pregnancy. Endokrynol Pol 2011; 62: 362-381.

24. Theodoropoulos T, Braverman LE, Vagenakis AG Iodide induced hypothyroidism: a potential hazard during perinatal life. Science 1979, 205: 502-503.

25. Brown RS, Bloomfield S, Bednarek FJ et al. Routine skin cleansing with povidone-iodine is not a common cause of transient neonatal hypothyroidism in North America: a prospective controlled study. Thyroid 1997; 7: 395-400.

26. Braverman LE, Roti E. Effects of iodine on thyroid function. Acta Med Austriaca 1996; 23: 4-9.

27. Delange F. Screening for congenital hypothyroidism used as an indicator of the degree of iodine deficiency and of its control. Thyroid 1998, 8: 1185-1192.

28. Costante G, Grasso L, Ludovico O et al. The statistical analysis of neonatal TSH results from congenital hypothyroidism screening programs provides a useful tool for the characterization of moderate iodine deficiency regions. J Endocrinol Invest 1997; 20: 251-256.

29. Nøhr S, Laurberg P. Opposite variations in maternal and neonatal thyroid function induced by iodine supplementation during pregnancy. J Clin Endocrinol Metab 2000; 85: 623-627.

30. Velasco I, Carreira M, Santiago P et al. Effect of iodine prophylaxis during pregnancy on neurocognitive development of children during the first two years of life. J Clin Endocrinol Metab 2009; 94: 3234-3241

31. Santiago P, Velasco I, Muela JA et al. Infant neurocognitive development is independent of the use of iodised salt or iodine supplements given during pregnancy. Br J Nutr 2013; 110: 831-839.

32. Rebagliato M, Muricia M, Alvarez-Pedrerol M et al. Iodine supplementation during pregnancy and infant neuropsychological development. INMA Mother and Child Cohort Study. Am J Epidemiol 2013; 177: 944-953.

33. Fisher DA, Klein AH. Thyroid development and disorders of thyroid function in the newborn. N Engl J Med 1981; 304: 702-712.

34. Food and Nutrition Board, Institute of Medicine Dietary reference intakes. Washington, DC: National Academy Press 2006; 320-327.

35. Berbel P, Mestre JL, Santamaría A et al. Delayed neurobehavioral development in children born to pregnant women with mild hypothyroxinemia during the first month of gestation: the importance of early iodine supplementation. Thyroid 2009; 1: 511-519.

36. Liesenkötter KP, Göpel W, Bogner U et al. Earliest prevention of endemic goiter by iodine supplementation during pregnancy. Eur J Endocrinol 1996; 134: 443-448. 